\title{
A new locality and host record for Enterogyrus coronatus (Pariselle Lambert \& Euzet (1991) in South Africa and a review of the morphology and distribution of Enterogyrus (Ancyrocephalidae) species
}

\author{
G. N. MADANIRE-MOYO, A. AVENANT-OLDEWAGE*
}

\begin{abstract}
Department of Zoology, University of Johannesburg, PO Box 524, Auckland Park, Johannesburg 2006, South Africa, E-mail: aoldewage@uj.ac.za
\end{abstract}

\begin{abstract}
Summary
Examination of 40 specimens of Pseudocrenilabrus philander philander (Weber, 1897) collected from Padda Dam $\left(26^{\circ} 10^{\prime} \mathrm{S} ; 17^{\circ} 59^{\prime} \mathrm{E}\right)$, South Africa revealed the presence of a stomach monogenean of the genus Enterogyrus (Paperna, 1963). The monogenean presented a prevalence of $52.5 \%$ and mean intensity of 4.2. The body, surrounded by a thick cuticle which is striated transversally, is dorso-ventrally flattened. The haptor has two pairs of gripi, a lightly sclerotised ventral transverse bar and marginal uncinuli. The dorsal gripus has a bifurcate root and a curved blade which is shorter than the shaft and is larger than that of the ventral gripus. The genetic distance between E. coronatus and the present Enterogyrus species $(0.24 \%)$ confirms the morphological similarities. This study presents a new locality and host record of the genus Enterogyrus from South Africa and a review of the morphology and distribution of Enterogyrus species is also given.
\end{abstract}

Keywords: Monogenea; Dactylogyridae; Enterogyrus; Pseudocrenilabrus philander philander; South Africa

\section{Introduction}

African fishes of the family Cichlidae are parasitized by five genera of monogeneans belonging to the family Dactylogyridae. The highly diversified Cichlidogyrus Paperna, 1960, Onchobdella Paperna, 1968 and Scutogyrus Pariselle \& Euzet, 1995 represent three genera infecting the gills. The two remaining genera; Enterogyrus Paperna, 1963 and Urogyrus Bilong Bilong et al. 1994 are endoparasitic, infecting the stomach and the urinary bladder, respectively. To date there are eight known species of Enterogyrus (Ancyrocephalidae), namely Enterogyrus cichlidarum Paperna, 1963; E. malmbergi Bilong Bilong, 1988; E. melenensis Bilong Bilong, Birgi \& Lambert, 1989; E. barombiensis Bilong Bilong, Birgi \& Euzet, 1991; E. foratus Pariselle, Lambert \& Euzet, 1991; E. coronatus Pariselle,
Lambert \& Euzet, 1991; E. amieti Bilong Bilong, Euzet \& Birgi, 1996 and E. crassus Bilong Bilong, Birgi \& Euzet, 1996. Previous records are mostly from West Africa (Bilong Bilong, 1988; Bilong Bilong et al., 1989; Bilong Bilong et al., 1991; Pariselle et al., 1991; Bilong Bilong et al., 1996) while a few records are from Egypt (Eid \& Negm, 1987; Khird, 1990) and Israel (Paperna, 1963). Other records are due to introductions of African hosts into other countries (Jiménez-Garcia et al., 2001; Jeronimo et al., 2010). In South Africa, there has been a single record of Enterogyrus species from Middle Letaba Dam, Limpopo Province (Olivier et al., 2009).

In all previous descriptions and records of enterogyrids, species determination has been carried out using morphology and size of sclerotised parts of the attachment organs. The reproductive cirrus has been used for resolving species level identification. Nevertheless, molecular data from Enterogyrus species is still very limited; with only three sequences of Enterogyrus species available on GenBank (Mendlová et al., 2010; 2012). The finding of many ancyrocephaline monogenean Enterogyrus specimens in the stomach of the southern mouthbrooder, Pseudocrenilabrus philander philander (Weber, 1897) prompted the present study. This paper presents the second record of Enterogyrus species from southern Africa, and uses both morphological and molecular data to identify the species from Padda Dam.

\section{Materials and methods}

Fish were collected in April 2013 on the University of Johannesburg grounds from the Padda Dam $\left(26^{\circ} 10^{\prime} \mathrm{S}\right.$; $\left.17^{\circ} 59^{\prime} \mathrm{E}\right)$. The dam is situated in the Westdene Tributary System which is one of the origins of the Limpopo River (South Africa). Fish were captured using hand nets and transported to the laboratory where they were kept in a holding tank with aerated dam water. Fish were killed by 
Table 1. Taxa used in the phylogenetic analysis of the Enterogyrus species in the current study

\begin{tabular}{llll}
\hline Parasite species & Host species & Locality & LSU \\
\hline Enterogyrus coronatus Pariselle, Lambert \& Euzet, 1995 & Tilapia dageti Thys van den Audenaerde, 1967 & Senegal, Africa & HQ010030 \\
Enterogyrus sp. 1 & Sarotherodon galilaeus (Linnaeus) & Senegal, Africa & HQ010032 \\
Enterogyrus sp. 2 & Sarotherodon galilaeus (Linnaeus) & Senegal, Africa & HQ010031 \\
Onchobdella aframae Paperna, 1968 & Hemichromis fasciatus Peters, 1857 & Senegal, Africa & HQ010033 \\
Onchobdella bopeleti Bilong Bilong \& Euzet, 1995 & Hemichromis fasciatus Peters, 1857 & Senegal, Africa & HQ010034 \\
\hline
\end{tabular}

severing the spinal cord immediately posterior to the cranium. The abdominal cavity of each fish was opened via a medio-saggital incision and the digestive system removed. The stomachs were removed, individually placed in Petri dishes containing $0.9 \%$ physiological saline and subsequently examined with the aid of a dissection microscope. The parasites which were anchored to the stomach wall were gently removed with the aid of a needle.

\section{Light microscopy studies}

A total of 30 parasites were preserved in $70 \%$ ethanol for light microscopy studies. Ten specimens were mounted on glass slides using Gray and Wess solution (Humason, 1979), covered with a cover slip and sealed with clear nail vanish. Ten additional specimens were stained with Hören's trichrome (Manual of Veterinary Parasitological Techniques, 1986) and five were stained with lignin pink and mounted in lacto phenol. A Zeiss Axioplan 2 imaging light microscope equipped with a camera and operated with Axiovision software (Carl Zeiss, Jena, Switzerland) was used to identify monogeneans through observations, micrographs, drawings and measurements. Measurements (in micrometres) are presented in the following order: (number of measurements) mean \pm standard deviation (minimum-maximum). Dimensions of the haptoral
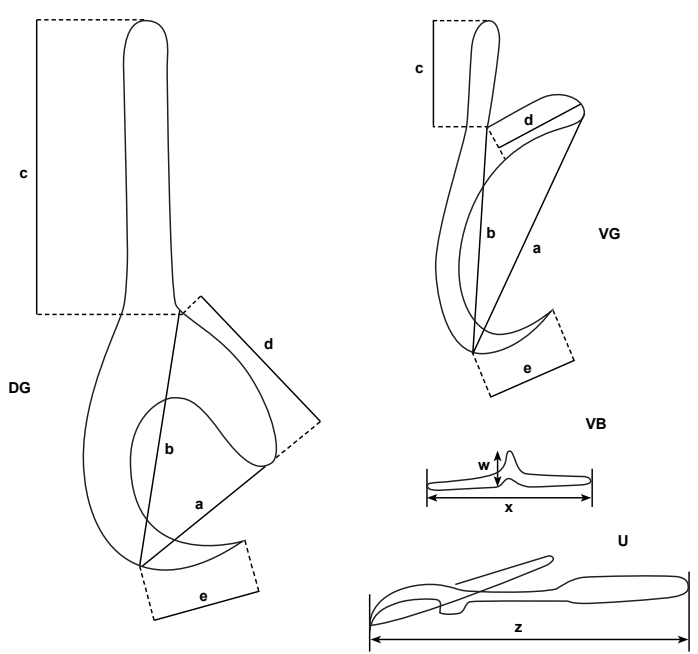

Fig. 1. Measurements of haptoral structures (after Gussev, 1962). $\mathrm{a}=$ anchor length $\mathrm{b}=$ blade; $\mathrm{c}=$ shaft; $\mathrm{d}=$ guard $\mathrm{DG}=$ dorsal gripus; $\mathrm{e}=$ point; $\mathrm{U}=$ uncinulus; $\mathrm{VB}=$ ventral transverse bar; $\mathrm{VG}=$ ventral gripus; $w=$ width of $\mathrm{VB} ; \mathrm{x}=$ length of $\mathrm{VB} ; \mathrm{z}=$ length of uncinulus structures (Fig. 1) used follow those of Gussev (1962) as amended by Bilong Bilong et al. (1989). The haptoral nomenclature follows that of Pariselle \& Euzet (1995). A comparison of the standardized measurements of sclerotised parts of known species of Enterogyrus (Table 1) was made by hierarchical clustering using IBM SPSS Statistics V. 21 (Statistical Package for Social Sciences, SPSS, Inc.).

\section{Scanning electron microscopy}

A total of 30 specimens were collected in this study, five of which were fixed and preserved in $70 \%$ ethanol (Merck, Germany) for scanning electron microscopy (SEM). Specimens were prepared by dehydrating them in a graded series of ethanol and subsequently in a graded series of hexamethyldisilazane (Merck, Germany) after Dos Santos et al. (2013). Samples were then sputter coated with gold and examined with a TESCAN Vega 3 LMH SEM (Brno, Czech Republic) at 5-10kV acceleration voltages.

\section{Genetic Analysis}

Five specimens were removed from the stomach wall and digested using a DNeasy ${ }^{\mathrm{TM}}$ Tissue kit (QIAGEN, Netherlands) to extract genomic DNA, as per the manufacturer's instructions. The large subunit region (LSU) of rDNA was amplified using primers $\mathrm{C} 1$ and D2 (Hassouna et al., 1984). The amplification reaction was performed using a MultiGene Gradient system (Labnet International, Inc., USA) using the parameters set out by Matejusová et al. (2001). The PCR products were run on a $1 \%$ agarose gel and sequenced similarly to the method used by AvenantOldewage et al. (2013).

These sequences were aligned and edited in GENEIOUS Pro $^{\text {TM }} 5.0$ software (Biomatters Ltd, New Zealand). All five sequences collapsed into a single haplotype and this sequence was aligned to the three other sequences for Enterogyrus retrieved from GenBank to determine the distinctness of this species. Sequences of two other dactylogyrid monogenea (Onchobdella) were recovered from GenBank to be used as outgroups in the phylogenetic reconstructions. The list of all taxa used for the present phylogenetic analyses is shown in Table 1. Sequence alignment was performed using MacClade4 (Maddison \& Maddison, 2005) with the resultant alignment analysed using PAUP 4* (Swofford, 2002). Genealogical relationships between taxa were analysed using parsimony, likelihood and distance approaches, with the robustness of their topologies assessed using 1000 bootstrap replicates. 

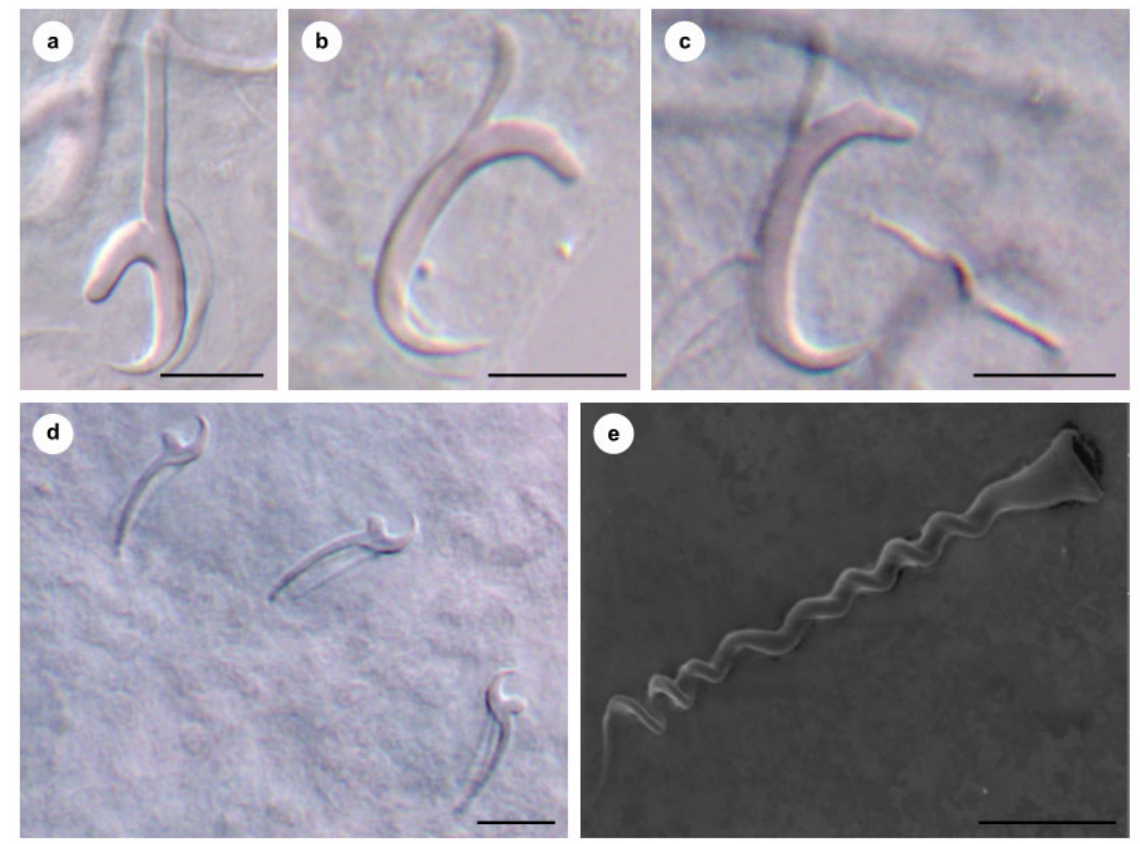

Fig. 2. Micrographs of sclerotised parts of Enterogyrus coronatus from the stomach of Pseudocrenilabrus philander. A= dorsal gripus; $\mathrm{B}=$ ventral gripus; $\mathrm{C}=$ uncinuli; $\mathrm{D}=$ ventral bar (arrow) $\mathrm{E}=$ light micrograph of the cirrus; $\mathrm{F}=$ scanning electron micrograph of the cirrus. Scale bars: $\mathrm{A}=10 \mu \mathrm{m} ; \mathrm{B}-\mathrm{D}=5 \mu \mathrm{m} ; \mathrm{D}=10 \mu \mathrm{m}$

\section{Results}

Description (Fig. 2A-E).

Body size is $(\mathrm{n}=22) 211 \pm 126(83.4-341.1) \mu \mathrm{m}$ long by $73.2 \pm 38(31.5-115.5) \mu \mathrm{m}$ wide at level of ovary. Small dorso-ventrally flattened, pear shaped. Thick, transversally-striated tegument around body. Anterior to pharynx are four dorsal ocelli: an anterior pair, small and wider spaced; posterior pair, larger than anterior pair, very close or in some specimens, merged on the median plane. Pharynx, medio ventrally positioned, $(\mathrm{n}=22) 16.5 \pm 7.7(10.5$ - 28.2) $\mu \mathrm{m}$ long and $15.6 \pm 7.3(9.5-26.5) \mu \mathrm{m}$ wide. Haptor is $(\mathrm{n}=22) 70.5 \pm 22.5(25.9-90.3) \mu \mathrm{m}$ at widest point and $70.5 \pm 22(26.7-92.7) \mu \mathrm{m}$ long, separated from

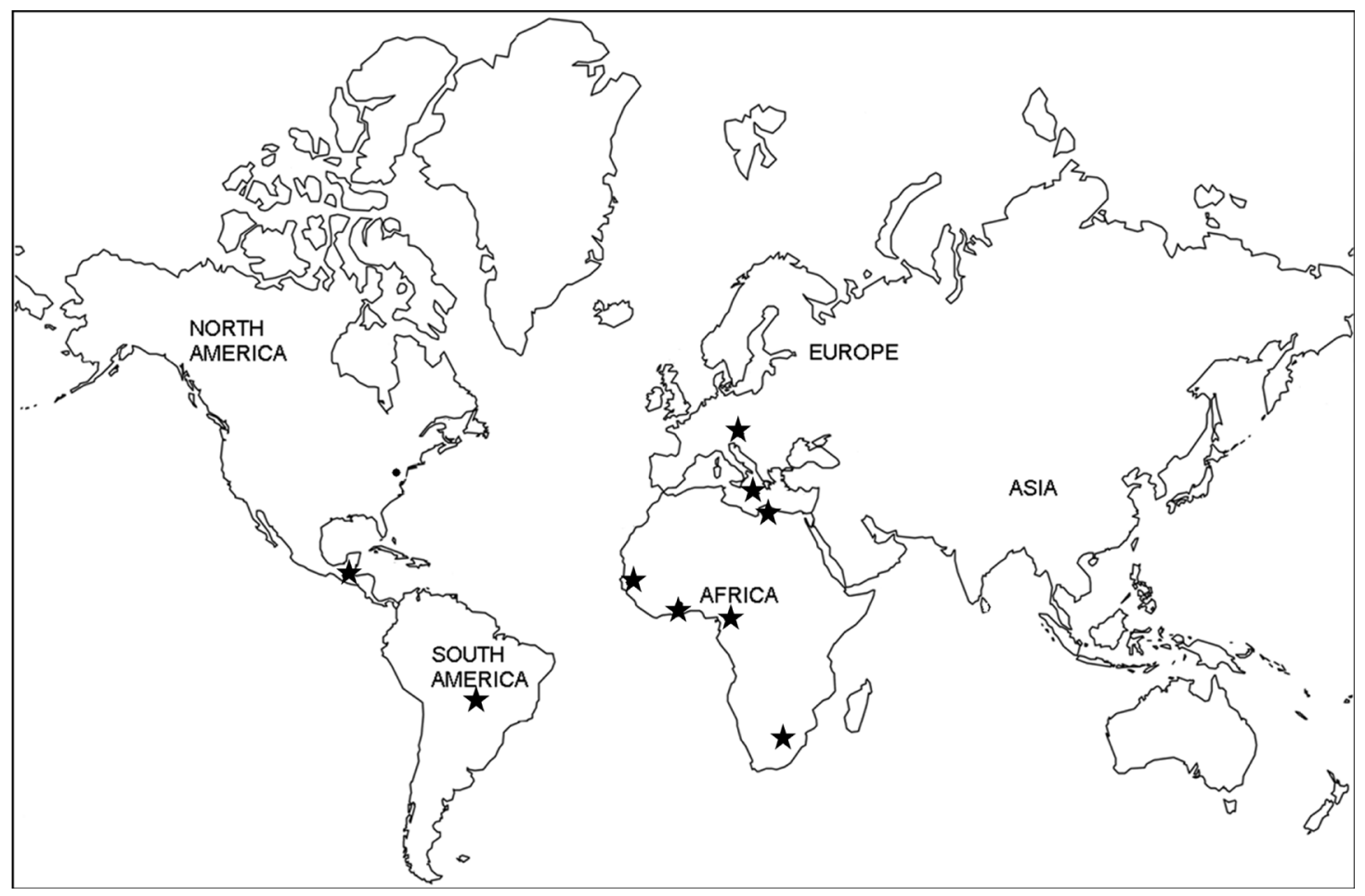

Fig. 3. Geographical distribution of Enterogyrus species 


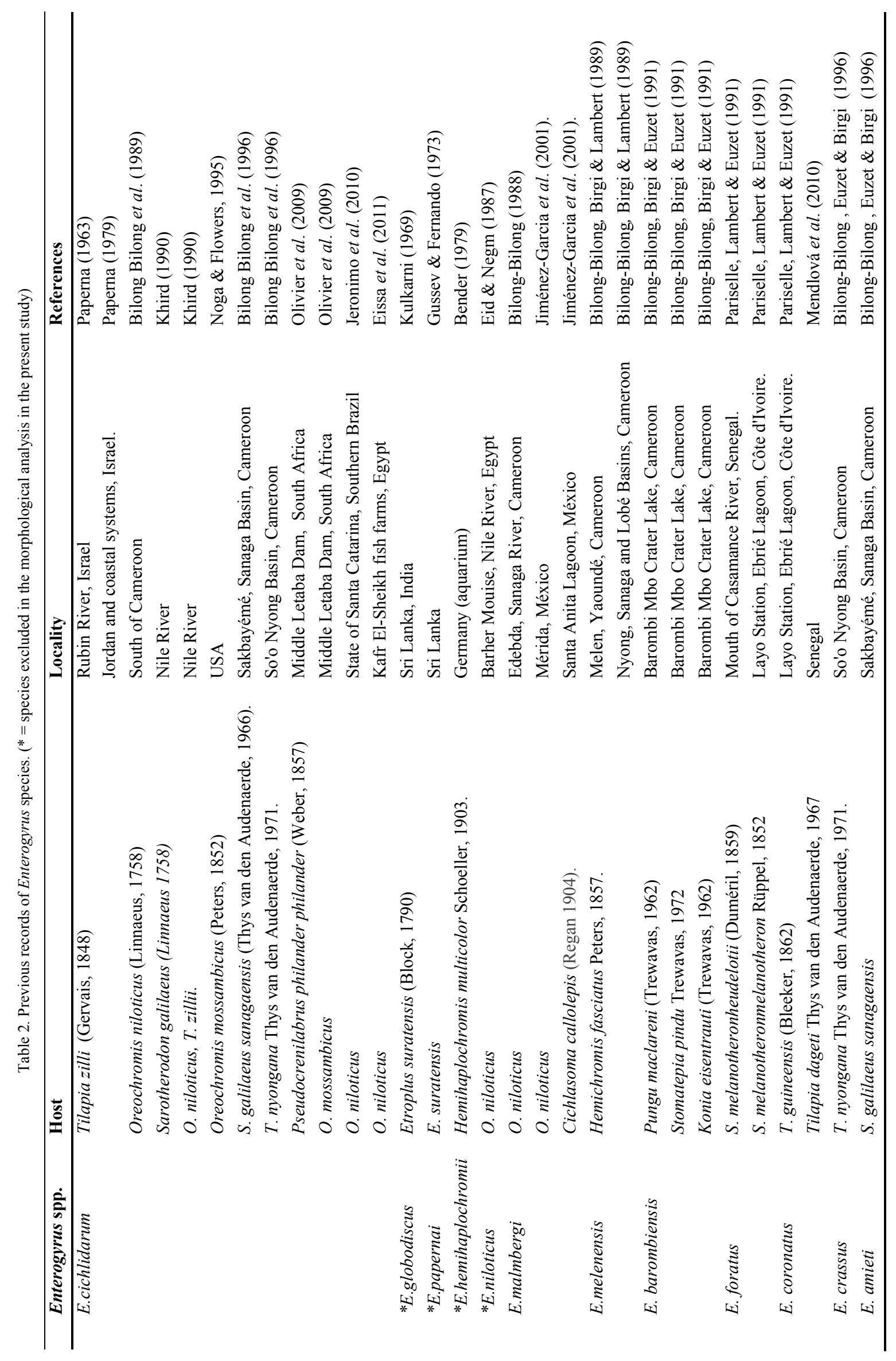




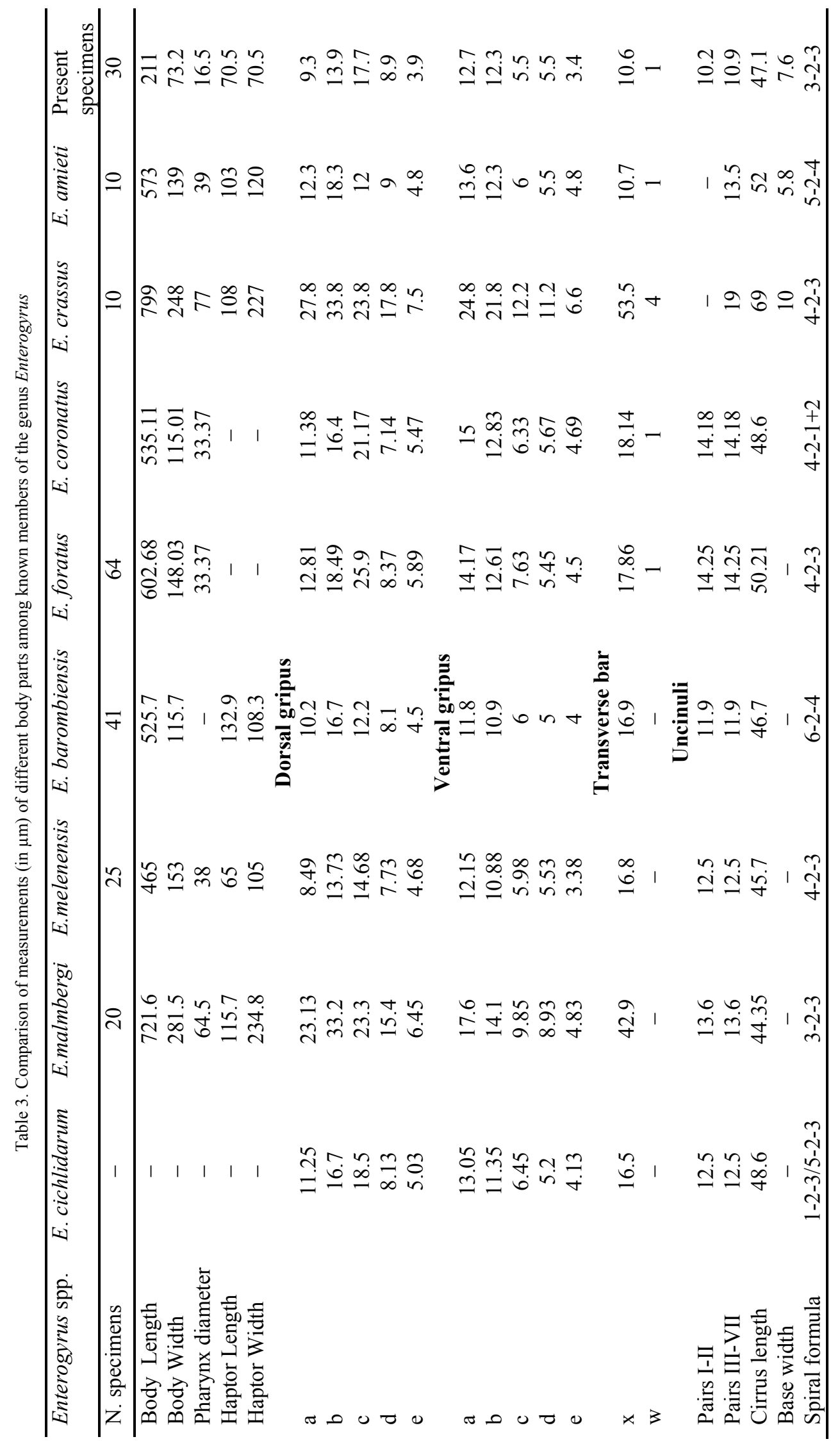




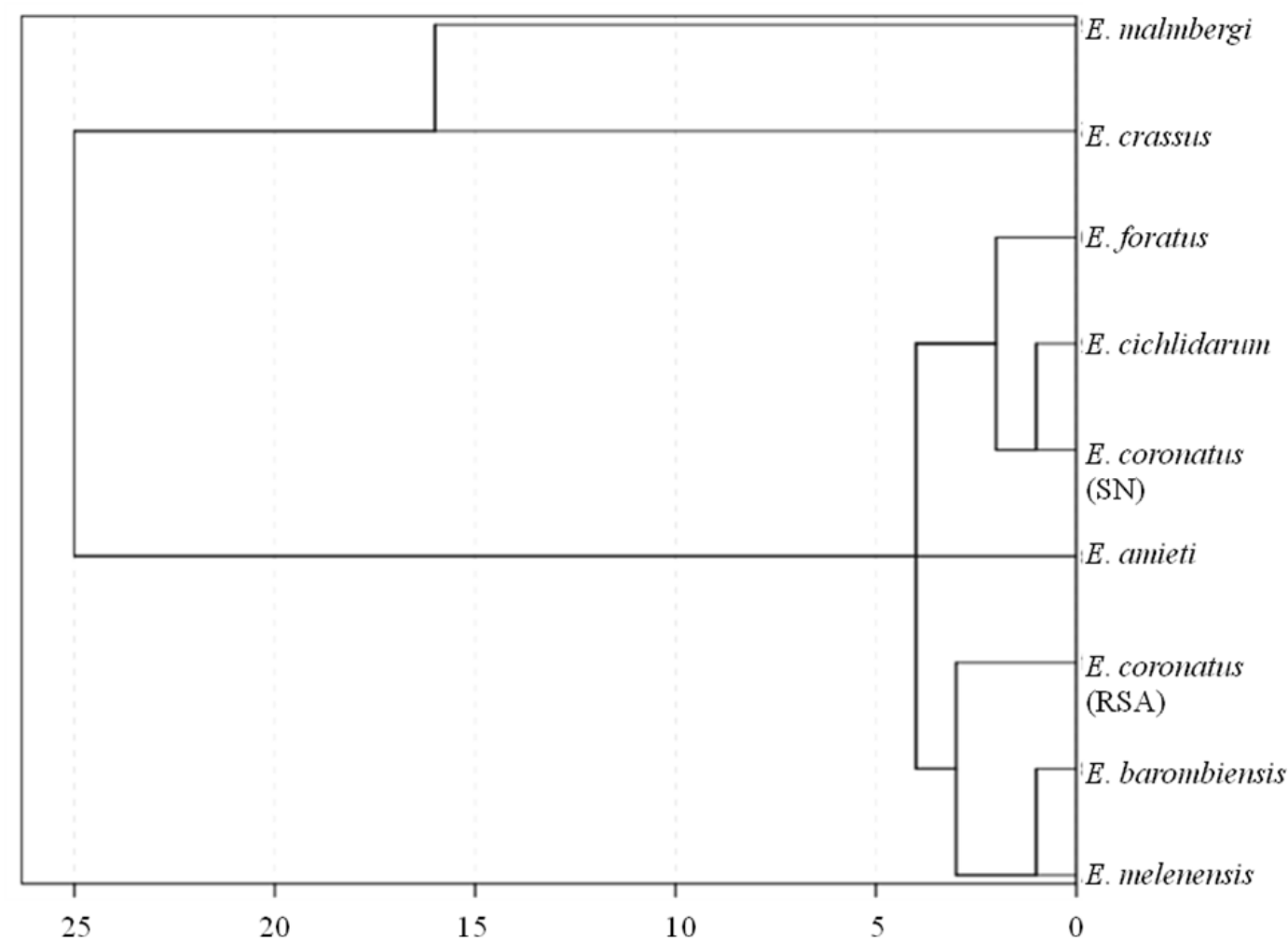

Fig. 4. Dendrogram for Euclidean hierarchical clustering based on standardised morphological data of the taxonomically important metric dimensions of the eight species of Enterogyrus described thus far

body by a slight constriction; has a thinner tegument which lacks transverse striations characteristic of main body. Two types of haptors observed in specimens: cup shaped haptor and tongue shaped haptor, each is armed with 14 uncinuli, 2 pairs of gripi (ventral and dorsal) and a lightly sclerotised transverse bar. Tongue shaped haptor comprises two segments: an elongate posterior penduncular segment bearing the dorsal and ventral gripi, the transverse bar and ventral uncinuli I and II; and a bulbous anterior segment with hooklets III - VII positioned in an equatorial sphere with their tips directed anteriorly. Dorsal gripus has shaft (c) which is longer than the blade $(b)$. Cirrus size $(n=10) 7.6$ $\pm 2.7(5.7-13.5) \mu \mathrm{m}$ wide at its base and $(\mathrm{n}=11) 47.1 \pm$ 15.1 (30.7 - 66.6) $\mu \mathrm{m}$ long, tubular, median, situated slightly posterior to pharynx, forming a continuous spiral as in other species of the genus. Between its base and distal extremity are series of 3 spirals, followed by 2 longer spirals, and finally 3 tightly packed distal spirals. The spiral pattern, as proposed by Pariselle et al. (1991), can be represented by the formula: 3-2-3. This spirality conforms to that described by Bilong Bilong et al. (1991) for E. malmbergi (Fig. 2E). This monogenean presented a prevalence of $52.5 \%$, mean intensity of 4.2 and a mean abundance of 2.2 in Padda Dam.

Although Enterogyrus globodiscus (Kulkarni, 1969), E. papernai (Gussev \& Fernando, 1973), E. niloticus (Eid \& Negm, 1987) and E. hemihaplochromii (Bender, 1979) appear in Table 2, these species have not been included in the morphological comparisons (Table 3 ). The type species, E. cichlidarum was recorded from Israel by Paperna in 1963. Subsequent findings were mostly from West Africa, with some records from Germany (Bender, 1979), America (Noga \& Flowers, 1995) and México (JiménezGarcia et al., 2001) (Table 2, Figure 3).

In order to identify the present specimens which were collected from the stomach of $P . p$. philander in Padda Dam, morphological comparisons with previously recorded Enterogyrus species were done (Table 3). There is limited genetic data on Enterogyrus species, hence a morphological phylogenetic comparison, based on haptoral metric dimensions was carried out and the results are presented in Figure 4. The metric dimensions of all analysed features of haptoral sclerites of the present species correspond closely with the measurements given for E. barombiensis and E. melenensis (Table 3, Figure 4). However, E. barombiensis is different from E. melenensis and the present specimens in that it has a smaller shaft to blade ratio, a characteristic seen in E. malmbergi, E. crassus and E. amieti. On the other hand, E. cichlidarum, E. foratus, E. coronatus have a bigger shaft to blade ratio (Table 3 ).

In general, there is no conspicuous variability in the dorsal and ventral gripi metric dimensions except in E. malmbergi and E. crassus, which have larger dimensions than the other six species. The former species also represent species with the longest transverse bars of $42.9 \mu \mathrm{m}$ and $53.5 \mu \mathrm{m}$, respectively. Furthermore, when only the cirrus length is considered, the present species is closely related to all the other species except for E. crassus whose cirrus is discernibly longer than that of the other seven species (Table 3). When the spirality of cirri of these three species was 


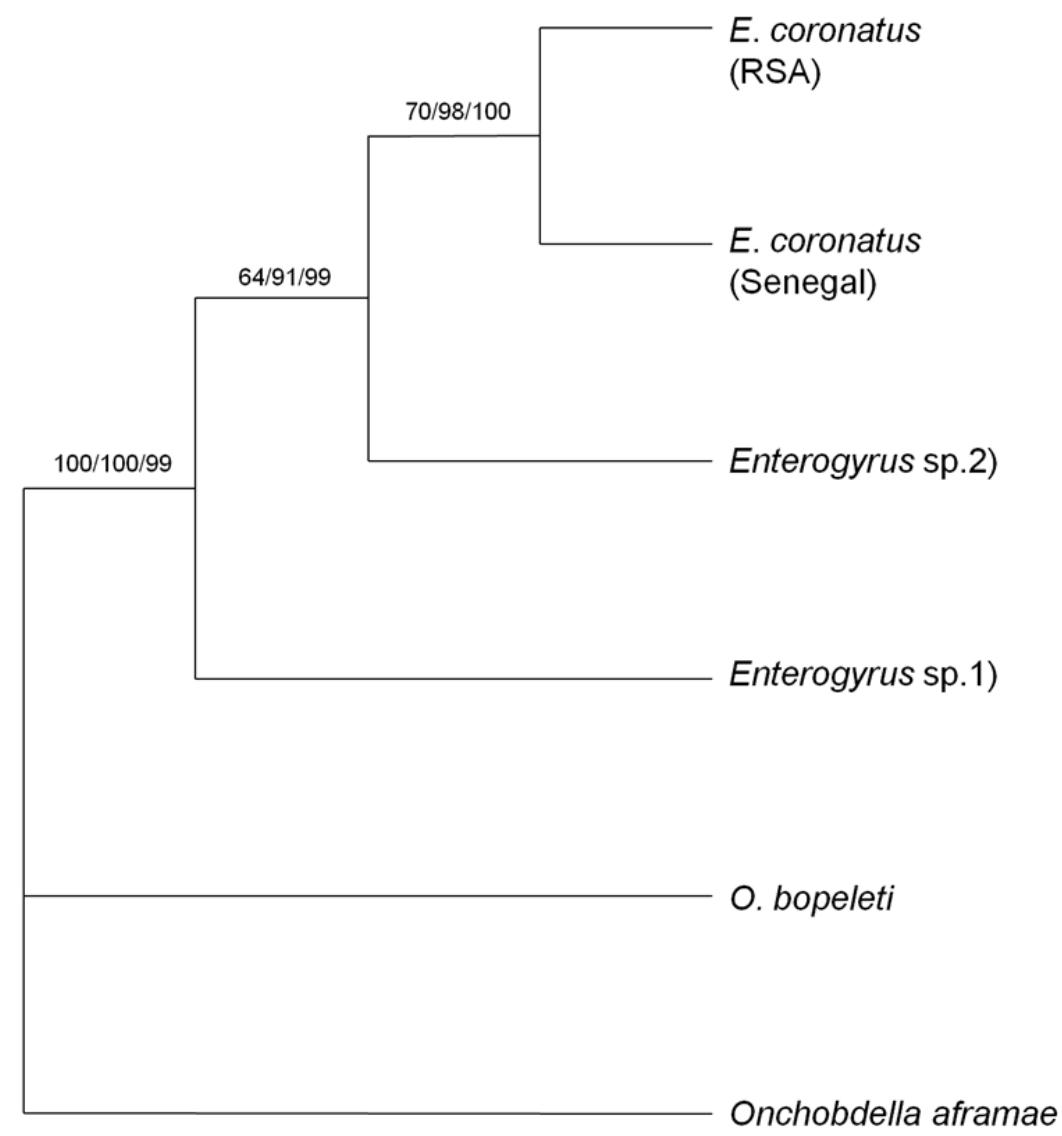

Fig. 5. Neigbour Joining tree based on parsimony methods inferred from the analysis of LSU rDNA sequences of three Enterogyrus species, two Onchobdella species and the Enterogyrus species in the current study. Bootstrap percentages for maximum likelihood, maximum parsimony and distance are shown above branches.

compared with that of the present species, a close resemblance with E. malmbergi was discerned. The spiral formulae E. cichlidarum is 1-2-3 and 5-2-3 while that of $E$. melenensis (4-2-3), is similar to that of E. foratus and $E$. crassus. Based on morphological data alone, the results were not conclusive enough to identify the specimens to species level; thus, molecular work was carried out to resolve these inconsistencies. The obtained genetic sequences of the South African specimens were very closely related to the sequence of E. coronatus from Senegal, except for two transitions in the LSU rDNA region. This was confirmed by the phyogenetic reconstruction in Figure 5, which displays similarity between E. coronatus from Senegal and that from South Africa. The partial LSU
rDNA sequences included four Enterogyrus species and two species of Onchobdella, Onchobdella aframae and $O$. bopeleti, which were included as outgroups (Table 1). Based on the analyses of LSU rDNA sequences, the six species of cichlid parasites formed a clade with Onchobdella aframae as the basal taxon (Fig. 5). Irrespective of the method of analysis, similar topologies were obtained and as such only a neighbor-joining tree is presented with the relevant statistical support indicated. There was no nucleotide variability (i.e. p-distance corresponding to 0.0024 ) between E. coronatus found in Tilapia dageti from Senegal and E. coronatus found in P. p. philander from South Africa (Table 4).

Table 4. Pair-wise genetic distances (\%) based on the LSU rDNA fragment of Enterogyrus from South Africa and other dactylogyrids from African cichlids

\begin{tabular}{|c|c|c|c|c|c|c|c|}
\hline & Parasite species & 1 & 2 & 3 & 4 & 5 & 6 \\
\hline 1 & Enterogyrus coronatus (RSA) & * & & & & & \\
\hline 2 & Enterogyrus coronatus & 0.24 & $*$ & & & & \\
\hline 3 & Enterogyrus sp. 1 & 7.70 & 7.95 & $*$ & & & \\
\hline 4 & Enterogyrus sp. 2 & 3.91 & 4.15 & 7.68 & $*$ & & \\
\hline 5 & Onchobdella bopeleti & 33.90 & 33.67 & 34.82 & 34.22 & $*$ & \\
\hline 6 & Onchobdella aframae & 34.53 & 34.29 & 35.55 & 34.71 & 5.23 & * \\
\hline
\end{tabular}




\section{Discussion}

Four species have been omitted in the morphological analyses carried out in this study. The two species, E. globodiscus and E. papernai, which were both described from Etroplus suratensis (Block, 1790) in Asia have two transverse bars compared to one for African and Levantine species. According to Pariselle \& Euzet (2009), this difference is sufficient to justify splitting Enterogyrus into two genera. Comparison of Enterogyrus species specimens from T. zillii and O. niloticus by Pariselle \& Euzet (2009) revealed no differences and thus $E$. niloticus was synonymised with $E$. cichlidarum. Enterogyrus hemihaplochromii was described in an unpublished thesis; hence this name is a nomen nudum (Pariselle \& Euzet, 2009). Thus, to date there are eight Enterogyrus species. The type species (E. cichlidarum) was recorded from Israel by Paperna in 1963. Subsequent findings were mostly from West Africa. The genus is confined to African cichlids but some Enterogyrus species have been introduced into Germany (Bender, 1979), America (Noga \& Flowers, 1995) and in México (Jiménez-Garcia et al. (2001) together with their African introduced hosts.

The posterior uncinuli (pairs I and II) of the present specimens are discernibly smaller and thinner than anterior uncinuli (pairs III to VII). This observation was consistent for all specimens in the present study and supplements the observations made by Bilong Bilong et al. (1996) for $E$. amieti. In spite of the fact that posterior and anterior uncinuli of the other known species are indicated as of equal lengths, careful analyses of illustrations reflect larger, thicker anterior uncinuli and smaller, thinner posterior uncinuli. This seems to be a constant feature for all species of Enterogyrus.

The organization of the haptor and morphology of the sclerotised structures of the present specimens is characteristic of the genus Enterogyrus. Although the specimens observed in this study possessed either a cup shaped or a tongue shaped haptor (Pariselle et al., 1991), the number and shape of the sclerotised parts of the haptor remained unaltered. The presence of two types of haptors was also observed in specimens of E. amieti described by Bilong Bilong et al. (1996). It is highly possible that the difference in haptor shape was brought about by specimen orientation during the preparation, fixing and mounting procedures. Some specimens may have retracted their haptors resulting in a cup shaped structure, while others may have extended their haptors have resulting in the tongue shaped structure. Enterogyrus coronatus was originally described from $\mathrm{Ti}$ lapia guineensis (Bleeker, 1862) in Côte d'Ivoire and subsequently recorded from Tilapia dageti Thys van den Audenaerde, 1967 in Senegal by Mendlová et al. (2010; 2012). The occurrence of this enterogyrid in $P . p$. philander from South Africa provides a new locality and host record. This is also the first time the parasite has been collected from a mouthbrooder. The majority of enterogyrid species recorded thus far show strict specificity towards their host. For example, E. crassus was found only in Tilapia nyongana Thys van den Audenaerde, 1971; E. amieti only in Sarotherodon galilaeus sanagaensis Thys van den Audenaerde, 1966; E. foratus only in Sarotherodon melanotheron heudelotii (Duméril, 1859) and E. melenensis only in Hemichromis fasciatus Peters, 1857. Enterogyrus malmbergi has been recorded in Oreochromis niloticus (Linnaeus, 1758). It is worth mentioning that under natural conditions, a single specimen of $E$. malmbergi was recovered from Cichlasoma callolepis, a cichlid native to México (Jiménez-Garcia et al. (2001). Four cichlid species (Tilapia zilli, O. niloticus, S. galilaeus sanagaensis, and T. nyongana) have been noted to host $E$. cichlidarum under natural conditions (Eid \& Negm, 1987; Bilong Bilong, et al., 1989; Khird, 1990; Paperna, 1963; Paperna, 1979; Bilong Bilong et al., 1996; Olivier et al., 2009; Jeronimo et al., 2010; Eissa et al., 2011). In addition, E. barombiensis has been recorded from Stomatepia pindu Trewavas, 1972 and from Konia eisentrauti (Trewavas, 1962) under natural conditions. Similar to E. cichlidarum and E.barombiensis; E. coronatus is thus a broad spectrum parasite; which infects both mouthbrooders (genus Pseudocrenilabrus) and substrate brooders (genus Tilapia).

Simultaneous occurrence of two congeneric Enterogyrus species; one with a broad spectrum and another with an oïoxenous specificity, has previously been reported by Bilong Bilong (1988) and Bilong Bilong et al. (1996). In the present study, only one enterogyrid species was recorded from $P$. p . philander. Similarly, only one oïoxenous Cichlidogyrus philander was recorded from the gills of the same host within the same locality (le Roux et al., 2011), even though a greater richness for other cichlidogyrid species has been reported in other localitites. For example, in Cichlidogyrus species, richness of 17 has been reported from T. guineensis (Pouyaudi et al., 2006).

Monogenean species determination is generally carried out using morphology and size of sclerotised parts of the haptoral and reproductive organs. Morphological characters have been used to infer phylogenetic relationships between monogenean species (Pouyaudi et al., 2006). Given the limited genetic data on Enterogyrus species, a morphological comparison approach, based on haptoral sclerites was followed in this study. This approach is open to extensive reconsideration once genetic data for most species are collected, as such data will add additional informative characters to morphological data. Although based on morphological data, the dendrogram obtained in this study provides the first interpretation on phylogenetic relationships among the enterogyrids. This should not be regarded as a definitive hypothesis on enterogyrid evolutionary history; the tree provides a phylogenetic hypothesis that may be tested based on molecular data.

Pouyaudi et al. (2006) suggests that the morphology of Ciclidogyrus and Scutogyrus haptoral sclerites is more useful for inferring phylogenetic relationships than the morphology of their reproductive organs. On the other hand, reproductive organs are more suitable for resolving species-level identification, presumably because of its faster rate of change (Pouyaudi et al., 2006). The use of the cirrus in Enterogyrus species determination was problematic in this study in view of the fact that different spe- 
cies presented inconspicuous differences in the length and spirality of the cirrus. For example, E. melenensis, E. foratus and $E$. crassus have a similar spirality of 4-2-3. This spiral formula is almost similar to that of E. coronatus which is $4-2-1+2$. It is noteworthy that $E$. cichlidarum has a spiral formula of 1-2-3 and 5-2-3 while E. barombiensis and $E$. amieti have unique spirality formulae. These inconsistencies make it difficult to identify enterogyrids to species level. In addition, based on measurements of both haptoral and reproductive morphology structures, the present specimens were found to be closely related to $E$. barombiensis and E. melenensis. However, E. barombiensis is distinct in having a dorsal gripus with a shaft that is shorter than the blade. The only morphological characters that E. coronatus shares with the present specimens are: bigger shaft to blade ratio and cirrus length, characteristics which are also shared with E. melenensis.

Furthermore, the present specimens are much smaller than E. coronatus type specimens collected from Côte d'Ivoire, thus, plasticity could be a possible explanation for this, demonstrating that geography, host related and environmental factors may influence the morphology of the hard parts. However, comprehensive sampling needs to be done across a wide range of geographical locations in order to make a more meaningful conclusion.

Although metrical dimensions of all analysed features of the haptoral sclerites and cirrus length and spirality of the specimens in this study did not correspond to those of $E$. coronatus, molecular work proved to be more useful in determining this species. The number of differences observed in the LSU rDNA region and the genetic distance of only $0.24 \%$ between $E$. coronatus and the present species confirms that this species is E. coronatus. Studies on all enterogyrid species, based on molecular work data are needed to accurately determine enterogyrids to species level. Furthermore, enterogyrid data from other cichlids are necessary to formulate hypotheses on the origin and evolutionary history of these seemingly closely related fauna of monogenean flatworms.

\section{Acknowledgements}

We thank Quinton Dos Santos, Lourelle Neethling, Lloyd Lynch and Beric Gilbert for their assistance in the field. This study was supported by the University of Johannesburg and National Research Foundation funding to AA-O.

\section{References}

Avenant-Oldewage, A., Le Roux, L. E., Mashego, S. N., JANSEN VAN VuUREN, B. (2013): Paradiplozoon ichthyoxanthon n. sp. (Monogenea: Diplozoidae) from Labeobarbus aeneus (Cyprinidae) in the Vaal River, South Africa. J. Helminthol. Available on CJ02013. DOI: 10.101 7/S0022149X12000879

BENDER, H. G. (1979): Zur Morphologie und Biologie von Enterogyrus hemihaplochromii n. sp. (Trematodes, Monogenea, Dactylogyridae, Ancyrocephalinae), einem Endo- parasiten bei Hemihaplochromis multicolor (Teleostei, Cichlidae). PhD Thesis, Zulassungsarbeit, West Germany: Zoologisches Institut der Universität Hohenheim

BILONG BILONG, C. F. (1988): Enterogyrus malmbergi n. sp, (Monogenea - Ancyrocephalidae) parasite de l'estomac du Cichlidae Tilapia nilotica Linné, 1757 au Sud-Cameroun. Ann. Fac. Sc. Bio-Biochim., 5: $51-58$

Bilong Bilong, C. F., Birgi, E., LAmBert, A. (1989): Enterogyrus melenensis n.sp. (Monogenea, Ancyrocephalidae), parasite stomacal de Hemichromis fasciatus Peters, 1857 (Téléostéen, Cichlidae) du Sud-Cameroun. Revue Zool. Afr., 1031: 99 - 105

Bilong Bilong, C. F., Birgi, E., Euzet, L. (1991): Enterogyrus barombiensis n. sp. (Monogenea, Ancyrocephalidae) parasite stomacal de trios Cichlidae endemiques lac de cratère Barombi Mbo (Cameroun). Ann. Parasitol. Hum. Comp., 66: 105 - 108

Bilong Bilong, C. F., Euzet, L., Birgi, E. (1996): Monogenean stomach parasites of cichlid fishes from Cameroon: Two new species of the genus Enterogyrus Paperna, 1963 (Ancyrocephalidae). Syst. Parasitol., 34(1): 37 - 42. DOI: 10.10007/BF01531208

Dos Santos, Q. M., Jansen Van VuUren, B., AvenantOldewage, A. (2013): Paradiplozoon vaalense n. sp. (Monogenea: Diplozoidae) from the gills of moggel, Labeo umbratus (Smith, 1841), in the Vaal River System. South Africa. J. Helminthol. Available on CJ02013. DOI: 10.1017/S0022149X1300059X

EID, N., NEGM, M. (1987): Some morphological study on a new species of endoparasitic monogenetic Trematode "Enterogyrus niloticus" in the intestine of Tilapia nilotica. J. Egypt. Vet. Med. Assoc., 47(1 - 2): $79-86$

EISSA, I. A. M., GAdO, M. S., IAILA, A. M., ZAKI, V. H., NoOR EL-DEEN, A. E. (2011): Field studies on prevailing internal parasitic diseases in male hybrid Tilapia in relation top monosex Tilapia at Kafr El-Sheikh Governorate fish farms. J. Am. Sci., 7 (3): $722-728$

Gussev, A. V. (1962): Monogenoidea. In: I. E BYCHOVSKAYA-PAVLOVSKAYA et al. (Ed) Key to parasites of freshwater fish of the USSR. Moscow-Leningrad. Moscow-Lenigrad: Academiya Nauk SSSR, 919 pp. (Translated from Russian by Israel Program for Scientific Translations, Ser. No. 1136, Jerusalem, 1964)

Gussev, A.V., Fernando, C. H. (1973): Dactylogyridae (Monogenoidea) from stomach of fishes. Folia Parasitol., 20(3): $207-212$

Hassouna, N., Michot, B., BAchellerie, J. P. (1984): The complete nucleotide sequence of mouse $28 \mathrm{~S}$ rRNA gene. Implications for the process of size increase of the large subunit rRNA in higher eukaryotes. Nucleic Acids Res., 12(8): 3563 - 3583

Humason, G. L. (1979): Animal Tissue Techniques. $4^{\text {th }}$ Edition, San Francisco, USA, Freeman and Co., 661pp. Jeronimo, G. T., Speck, G. M., Martins, M. L. (2010): First report of Enterogyrus cichlidarum Paperna 1963 (Monogenoidea: Ancyrocephalidae) on Nile Tilapia Oreochromis niloticus cultured in Brazil. Neotrop. Helminthol., (4 (1): $75-80$ 
JiMÉNEZ-GARCIA, M. I., VidAL-MARTINEZ, V. M., LÓPEZJIMÉNEZ, S. (2001): Monogeneans in introduced and native cichlids in México: evidence for transfer. J. Parasitol., 87(4): 907 - 909. DOI: $10.2307 / 3285151$

KHIDR, A. A. (1990): Population dynamics of Enterogyrus cichlidarum (Monogenea: Ancyrocephalinae) from the stomach of Tilapia species in Egypt. Int. J. Parasitol., 20(6): $741-745$

KULKARNI, T. (1969): Studies on the monogenetic trematodes of fishes found in Hyderabad, Andhra Pradesh (India) - Part II. Rivista di Parassitologia, 30(2): 263 - 282

MAdDison, D. R., MAdDISON, W. P. (2005): MacClade Version 3 [computer software]. Sunderlan, MA: Sinauer Associates

Matejusová, I., KoubKova, B., D’Amelio, S., CunNinghaM, C. (2001): Genetic characterization of six species of diplozoids (Monogenea; Diplozoidae). Parasitology, 123(5): $465-474$

Mendlová, M., Pariselle, A., VyskočIlová, M., ŠIMKOVÁ, A. (2010): Molecular phylogeny of monogeneans parasitizing African freshwater Cichlidae inferred from LSU rDNA sequences. Parasitol. Res. 107(6): 1405 1413. DOI: 10.1007/s00436-010-2008-6

Mendlová, M., Desdevises, Y., CiváŇovÁ, K., PAriselle, A., ŠImKovÁ, A. (2012): Monogeneans of West African Cichlid Fish: Evolution and Cophylogenetic Interactions. PLoS ONE 7(5): e37268. Retrieved August 23, 2013 from PLoS ONE database DOI: 10.1371/journal.pone.0037268

NATiOn, J. L. (1983). A New Method Using Hexamethyldisilazane for preparation of soft insect tissues for scanning electron microscopy. Stain Technol., 58(6): 347 - 351. DOI: $10.3109 / 10520298309066811$

NogA, E. D., Flowers J. R. (1995): Invasion of Tilapia mossambica (Cichlidae) viscera by the monogenean Enterogyrus cichlidarum. J. Parasitol., 81: 815 - 817. DOI: 10.2307/3283988

Olivier, P. A. S., LuUs-Powell, W. J., SaAyman, J. E. (2009): Report on some monogenean and clinostomid infestations of freshwater fish and waterbird hosts in Middle Letaba Dam, Limpopo Province, South Africa. Onderstepoort J. Vet. Res., 76: 187 - 199. DOI: 10.4102/ ojvr.v76i2.44

PAPERNA, I. (1963): Enterogyrus cichlidarum n. gen. n. sp., a monogenetic trematode parasitic in the intestine of fish. Bull. Res. Counc. Isr., 11B: 183 - 187

PAPERNA, I. (1979): Monogenea of inland water fish in Africa. Ann. Musee Roy. Afr. Centr., 226: 1 - 131

Pariselle, A., LAmbert, A., Euzet, L. (1991): A new type of haptor in mesoparasitic monogeneans of the genus Enterogyrus Paperna, 1963, with a description of Enterogyrus foratus n. sp. and E. coronatus n. sp, stomach parasites of cichlids in West Africa. Syst. Parasitol., 20: 211 220. DOI: $10.1007 / \mathrm{BF} 00009785$

PAriselle, A., Euzet, L. (1995). Gill parasites of the genus Cichlidogyrus Paperna, 1960 (Monogenea, Ancyrocephalidae) from Tilapia guineensis (Bleeker, 1862), with descriptions of six new species. Syst. Parasitol., 30 (3): 187 - 198. DOI: $10.1007 /$ BF00010469

PARISElle, A., EuZET, L. (2009): Systematic revision of dactylogyridean parasites (Monogenea) from cichlid fishes in Africa, the Levant and Madagascar. Zoosystema 31: 849 - 898. DOI: $10.5252 / \mathrm{z} 2009 \mathrm{n} 4 \mathrm{a} 6$

Pariselle, A., Boeger, W., Snoeks, J., Bilong Bilong C., Morand, S., Vanhove, M. (2011): The monogenean parasite fauna of cichlids: a potential tool for host biogeography. Int. J. Evol. Biol., 2011, 15 pp. DOI: 10.4061/2011/471480

Pouyaud, L., Desmarais, E., Deveney, M., Pariselle, A. (2006): Phylogenetic relationships among monogenean gill parasites (Dactylogyridea, Ancyrocephalidae) infesting tilapiine hosts (Cichlidae): systematic and evolutionary implications. Mol. Phylogenet. Evol., 38: 241 - 249. DOI: 10.1016/j.ympev.2005.08.013

SwOFFORD, D. L. (2002): PAUP*- Phylogenetic Analysis Using Parsimony. v.4.0b10 [computer software]. Sunderlan, MA: Sinauer Associates

ACCEPTED FEBRUARY 23, 2014 